\title{
Impact of summer moong through improved technology in Jalandhar district of Punjab, India
}

\author{
Pawan Kumar* and Arpandeep Kaur Boparai \\ Punjab Agricultural University, Krishi Vigyan Kendra, Nurmahal - 144039 \\ Jalandhar (Punjab), India \\ *Corresponding author
}

\begin{abstract}
A B S T R A C T
\section{Keywords}

Summer moong; Demonstration; technology index; economic returns; impact

Article Info

\section{Accepted:}

28 April 2020

Available Online:

10 May 2020

Frontline demonstrations (FLDs) are the important extension techniques to convince the farmers about latest farm technologies. The present study was conducted to assess the impact of frontline demonstrations on summer moong crop conducted in Jalandhar district of Punjab. Study revealed that improved cultivation practices comprised under FLDs viz., recommended varieties, seed rate, timely sowing and plant protection technology resulted in average increase in yield of 18.73 per cent in summer moong over the check plots. Technology gaps, extension gaps and technology indices were calculated to analyze the performance of these frontline demonstrations at farmers' fields. Lower average technology index of 3.45 per cent indicates the feasibility of summer moong crop in existing farming situation in the district. The improved production technology of these pulses gave higher gross return and net return with higher benefit-cost ratio in FLD plots (2.21) as compared to check plots (1.79).
\end{abstract}

\section{Introduction}

In Punjab (India), moong is one of the major pulse crops. The crop is grown during summer as well as kharif (rainy) season. Efforts are on to develop improved varieties, production and protection technology of moongbean cultivation for increasing area and productivity. In Jalandhar district of Punjab have an intensive cropping system like ricewheat; rice-potato-maize and rice-potatofodder.
However, summer moong in summer season have very negligible area due to some technological gap. So that the summer moong can fit well in summer season and form the rice-potato-summer moong cropping system instead to rice-potato-maize. It has helpful for increase the area of pulses in Jalandhar district. Front line demonstrations conducted on farmer's field help to identify the constraints and potential of the moong in specific area as well as it helps in improving the economic and social status of the farmers. 
The aim of the front line demonstration is to convey the technical message to farmers that if they use recommended package and practices then yield can be improved. The adoption levels for several components of the improved technology were very low, emphasizing the need for better dissemination. Several biotic, abiotic and socio-economic constraints inhibit exploitation of the yield potential and those needs to be addressed. Integrated management of yellow mosaic disease emphasized in moongbean by Sunil Kulkarni, 2019. The Jalandhar district of Punjab has sizeable area under summer moong cultivation and productivity level is very low instead of maize in summer season. The reasons for low productivity are poor knowledge about improved crop production technologies and their management practices in farmer's field. Keeping the above point in view, the frontline demonstrations was conducted with the objective of sowing the productivity potentials of the improved production technologies under actual farm situation.

\section{Materials and Methods}

The study was conducted in Jalandhar district of Punjab from 2015-16 to 2018-19. During this period 138 frontline demonstrations (FLDs) were conducted in 56 ha areas in farmers field. Materials and recommendation were followed in the present study with respect to FLD as: (i) Improved variety of summer moong; (ii) Seed treatment with fungicides and inoculated with consortium biofertilizer (iii) Adoption of IPM for control of the insect-pest and diseases. The sowing was done apart of $22.5 \mathrm{~cm}$ with maintain the distance about $7 \mathrm{~cm}$ from plant to plant and 4 to $6 \mathrm{~cm}$ deep with pora method during month of March. Regular visits by the KVK scientists to demonstration fields were ensured and made to guide the farmers. These visits were also utilized to collect feedback information for further improvement in research and extension programmes. Field days and group meetings were also organized at the demonstration sites to provide the opportunities for other farmers to witness the benefits of demonstrated technologies. The necessary steps for selection of site and farmers, layout of demonstration etc. were followed as suggested by Choudhary (1999). The traditional practices were maintained in case of local checks. The data were collected from both frontline demonstration plots as well as check plots (farmers practices) and finally the extension gap, technology gap and technology index were worked out (Samui et al., 2000) as given below:

Technology gap $=$ Potential yield - Check yield

Extension gap=Demonstration yield - Check yield

$$
\text { Technology Index }=\frac{\text { Potential yield }- \text { Demonstration yield }}{\text { Potential yield }} 100
$$

\section{Results and Discussion}

The existing and recommended technologies of summer moong and gap between them have been presented in Table 1. A substantial gap was observed in the source of purchase of improved variety, weeding, irrigation and plant protection, which definitely was the reason for not achieving the potential yield. Farmers in general purchased local seeds available with local shopkeepers without any variety name. Seed of improved varieties was not available to them; neither had they habit to take seeds of improved varieties from Government institutions. Farmer also purchased the seed of recommended variety to other farmers. But the variety comes various times under cultivation. Therefore, variety has been prone to insect-pest and disease like moongbean yellow mosaic virus. Recommended varieties SML 668 and SML 
832 were demonstrated at farmers' fields with the local variety as farmer practice. Demonstrations were laid following recommended time of sowing from 20 March to 10 April to avoid pre-monsoon rainfall at the harvesting stage. In check plots farmers usually delayed the sowing of summer moong till end of April and followed broadcasting method of sowing. Farmers generally use less seed rate than recommended and usually go for broadcast method rather than line sowing which make the inter cultural operations difficult and optimum plant population cannot be achieved that lead to undue competition between the plants and ultimately reduction in yield. It was also observed that farmers applied more than recommended dose of urea in their fields and did not use any herbicide for weed control. Also, they did not use the recommended pesticides for insect pest management in summer moong. To protect the crop from seed borne diseases, seed treatment and seed inoculation with biofertilizer were done but none of the farmers adopted this practice and it resulted into more number of sprays without taking care of the economic threshold levels which increased the cost of cultivation per unit area. Considerable gaps were observed in almost all crop operations starting from source of purchase of variety, seed rate, seed treatment, method of sowing, plant protection measures, etc. Similar observations for gap in improved technologies and farmers' practices were also observed by Singh et al. (2017a) in summer moong crop.

\section{Yield of performance of demonstration}

The grain yield of summer moong obtained over the years under recommended practices are presented in Table 2. During summer season 2015-16, some demonstrations were conducted in months of March after harvest of potato crop give the good results ranged 13.75 $\mathrm{q} /$ ha to $7.92 \mathrm{q} /$ ha with mean yield of 10.48 q/ha. Similar results observed by Singh et al. (2012) in Amritsar district of Punjab and observed that the average yield of summer moong in FLD plots sown after potato crop was highest $(12.37 \mathrm{q} / \mathrm{ha})$ and least yield of $9.14 \mathrm{q} / \mathrm{ha}$ was obtained in the summer moong sown after wheat crop. However, during season 2015-16, the trials also conducted in first fortnight of May of after harvest of wheat not give satisfactory results because the crop was come under rainy days at the time of maturity and recorded low grain yield ranged $7.50 \mathrm{q} / \mathrm{ha}$ to $3.00 \mathrm{q} / \mathrm{ha}$ with mean yield of 4.65 q/ha.

During summer season 2016-17, demonstrations conducted after harvest of potato, gobhi sarson and fodder crop and obtained grain yield $13.50 \mathrm{q} / \mathrm{ha}$ to $9.50 \mathrm{q} / \mathrm{ha}$ with mean yield of $11.08 \mathrm{q} / \mathrm{ha}$. During summer season 2017-18, average yield 11.15 $\mathrm{q} /$ ha was recorded from demonstrated plots while the ranged 8.84 to $15.25 \mathrm{q} /$ ha. During 2018-19, introduced new variety of summer moong cv. SML 832 in demonstration and obtained an average yield of $12.9 \mathrm{q} / \mathrm{ha}$ and maximum yield in demonstration of this variety was recorded $16.25 \mathrm{q} / \mathrm{ha}$.

Efforts are on to develop different cropping system in this region with involved the summer moong crop like rice-potato-summer moong, rice-gobhi sarson-summer moong and rice-fodder crop-summer moong. It is helpful for the increase in area of pulses in Jalandhar district. It also has a great scope in crop diversification and can help in sustaining crop productivity. Singh et al. (2017 b) observed that the recommended technology produced 11.0 and 12.3 per cent more seed yield and 12.3 and 15.6 per cent higher net returns of summer moong cv. SML 668 than the crop raised by existing technology in first and second year, respectively in Amritsar and Tarntaran districts of Punjab. Singh, (2017 a) conducted FLDs of summer moong viz., 
recommended varieties SML 668 and SML 832, seed rate, timely sowing and plant protection technology resulted in average increase in yield of 15.7 per cent over the check plots in Moga district of Punjab. Kumar and Kispotta (2017) conducted demonstration of improved moong variety Samrat in Bhadohi district of Uttar Pradesh and recorded the higher yield $6.82 \mathrm{q} /$ ha and 7.39 $\mathrm{q} /$ ha compared to the farmers' practice variety $4.56 \mathrm{q} / \mathrm{ha}$ and $5.25 \mathrm{q} / \mathrm{ha}$ in the year 2015 and 2016, respectively.

\section{Yield gap analysis of FLDs}

Data comparison of yield performance between demonstrated practices and local checks is shown in Table 3. Yield performance of summer moong variety SML 668 and SML 832 was described here only which has sown in month of March after harvesting of potato, gobhi sarson and fodder crops during summer season. It was observed that the average grain yield (10.48 q/ha) when compared to farmers practices $(8.85 \mathrm{q} / \mathrm{ha})$ with increase in the yield over local check was $18.42 \%$ during summer season 2015-16. In season 2016-17, yield performance was recorded as average grain yield (11.08 q/ha) when compared to farmers practices (9.28 $\mathrm{q} / \mathrm{ha}$ ) with increase in the yield over local check was $19.4 \%$.

However, in 2017-18 the average yield was recorded $11.15 \mathrm{q}$ per ha. An average yield of $12.9 \mathrm{q} / \mathrm{ha}$ was recorded during the year 201819 as compared to farmers practice (10.5 $\mathrm{q} / \mathrm{ha}$ ) with an increase of $22.85 \%$ over the check plot. Similar yield enhancement in summer moong in different trials has been documented in Amritsar (Singh et al. 2012), Moga (Singh et al. 2017 a), Amritsar and Tarntaran (Singh et al. 2017 b) Bhadohi district of Uttar Pradesh by Kumar and Kispotta (2017), It is evident from the results that the yield of improved YVM resistance variety was found better than the local check under same environment conditions. Farmers were motivated by results of demonstrated agro technologies applied in the FLDs and it is anticipated that they would adopt these technologies in future. The higher grain yield of moong crop obtained under recommended practice was due to the use of improved variety, recommended seed rate, use of biofertilizers, recommended fertilizer dose, preemergence weed management etc.

\section{Technology and extension gap}

The technology gap is the difference between the demonstration yield and potential yield and it was $0.41 \mathrm{q} / \mathrm{ha}$. This gap exists due to variation in the soil fertility and climatic conditions. Hence location specific recommendations are necessary to bridge the gap. The extension gap ranging from 1.39 $\mathrm{q} / \mathrm{ha}$ to $2.40 \mathrm{q} / \mathrm{ha}$ during the period of study emphasizes the need to educate the farmers through various means for adoption of improved agricultural production technologies to reverse the trend.

The average extension gap was observed 1.80 q/ha. Technology index showed the feasibility of evolved technology at the farmer's field. The wider in technology index ranging between $0.88 \%$ and $6.84 \%$ during the period may be attributed to the difference in the soil fertility status, weather condition and insectpest attack on the crop. Result of present study depicted in Table- 3, revealed that the technology index values were $3.45 \%$. Technology gaps, extension gaps and technology indices were calculated to analyze the performance of these frontline demonstrations at farmers' fields. Lower average technology index indicates the feasibility of summer moong crop in existing farming situation (Singh et al., 2017 a). 
Table.1 Comparison between demonstration package and existing farmers' practices of summer moong

\begin{tabular}{|c|c|c|}
\hline Particulars & Demonstration Package & Farmers Practice \\
\hline Improved variety & SML 668 \& SML 832 & Local Variety \\
\hline Seed rate & $\begin{array}{l}\text { SML668@37.5 kg \& SML } 832 @ 30 \text { kg per } \\
\text { ha }\end{array}$ & $25 \mathrm{~kg} / \mathrm{ha}$ \\
\hline Time of sowing & 20 March to 10 April & $2^{\text {nd }}$ fortnight of April \\
\hline Method of sowing & Line Sowing $(22.5 \mathrm{~cm} \mathrm{x} 7 \mathrm{~cm})$ & Broadcasting \\
\hline Seed treatment & Carbendazim 50 WP @ $2.5 \mathrm{gm} / \mathrm{kg}$ seed & No seed treatment \\
\hline Use of Bio-fertilizer & Seed inoculation with consortium biofertilizer & No Inoculation \\
\hline $\begin{array}{l}\text { Basal Application of } \\
\text { Fertilizers }\end{array}$ & $\begin{array}{l}27.5 \mathrm{~kg} / \mathrm{ha} \text { Urea }+250 \mathrm{~kg} / \mathrm{ha} \text { SSP } \\
\text { (No fertilizer applied after potato crop) }\end{array}$ & $\begin{array}{l}\text { Irrational used of nitrogenous fertilizers } \\
\text { and non-application of SSP }\end{array}$ \\
\hline Weed Management & Stomp 30 EC @ 2.5 lit /ha & Not used \\
\hline Plant protection measures & $\begin{array}{l}\text { Need based spray of insecticides and } \\
\text { fungicides }\end{array}$ & $\begin{array}{l}\text { Over dose/ un recommended brands of } \\
\text { insecticides and fungicides }\end{array}$ \\
\hline
\end{tabular}

Table.2 Grain yield of summer moong trial conducted during summer

\begin{tabular}{|l|l|c|c|c|c|c|l|}
\hline Season & Variety & $\begin{array}{c}\text { No. of trial } \\
\text { conducted }\end{array}$ & $\begin{array}{c}\text { Total } \\
\text { area } \\
\text { (ha) }\end{array}$ & $\begin{array}{c}\text { Average } \\
\text { yield } \\
\text { (q/ha) }\end{array}$ & $\begin{array}{c}\text { Minimum } \\
\text { yield } \\
\text { (q/ha) }\end{array}$ & $\begin{array}{c}\text { Maximum } \\
\text { yield } \\
\text { (q/ha) }\end{array}$ & Remark \\
\hline $\mathbf{2 0 1 5 - 1 6}$ & $\begin{array}{l}\text { SML } \\
668\end{array}$ & 24 & 9 & 10.48 & 7.92 & 13.75 & Sown after harvest of potato \\
\hline $\mathbf{2 0 1 6 - 1 7}$ & $\begin{array}{l}\text { SML } \\
\text { 668 }\end{array}$ & 25 & 14 & 11.08 & 9.50 & 13.5 & $\begin{array}{l}\text { Sown after harvest of potato, } \\
\text { gobhi sarson and fodder crop }\end{array}$ \\
\hline $\mathbf{2 0 1 7 - 1 8}$ & $\begin{array}{l}\text { SML } \\
\text { 668 }\end{array}$ & 50 & 20 & 11.15 & 8.84 & 15.25 & $\begin{array}{l}\text { Sown after harvest of potato, } \\
\text { gobhi sarson and fodder crop }\end{array}$ \\
\hline $\mathbf{2 0 1 8 - 1 9}$ & $\begin{array}{l}\text { SML } \\
\text { SM2 }\end{array}$ & 25 & 10 & 12.9 & 10.50 & 16.25 & $\begin{array}{l}\text { Sown after harvest of potato, } \\
\text { gobhi sarson and fodder crop }\end{array}$ \\
\hline
\end{tabular}

Table.3 Grain yield and gap analysis of front line demonstrations on summer moong

\begin{tabular}{|c|c|c|c|c|c|c|c|c|}
\hline \multirow[t]{2}{*}{ Season } & \multirow[t]{2}{*}{ Variety } & \multicolumn{3}{|c|}{ Yield (q/ha) } & \multirow{2}{*}{$\begin{array}{l}\text { Per cent } \\
\text { increase }\end{array}$} & \multirow{2}{*}{$\begin{array}{l}\text { Technology } \\
\text { gap (q/ha) }\end{array}$} & \multirow{2}{*}{$\begin{array}{c}\text { Extension gap } \\
\text { (q/ha) }\end{array}$} & \multirow{2}{*}{$\begin{array}{c}\text { Technology } \\
\text { index }(\%)\end{array}$} \\
\hline & & Potential & Demonstration & Check & & & & \\
\hline 2015-16 & SML 668 & 11.25 & 10.48 & 8.85 & 18.42 & 0.77 & 1.63 & 6.84 \\
\hline 2016-17 & SML 668 & 11.25 & 11.08 & 9.28 & 19.40 & 0.17 & 1.80 & 1.51 \\
\hline 2017-18 & SML 668 & 11.25 & 11.15 & 9.76 & 14.24 & 0.10 & 1.39 & 0.88 \\
\hline 2018-19 & SML 832 & 13.52 & 12.9 & 10.5 & 22.85 & 0.62 & 2.40 & 4.58 \\
\hline \multicolumn{2}{|c|}{ Mean } & - & 11.40 & 9.60 & 18.73 & 0.41 & 1.80 & 3.45 \\
\hline
\end{tabular}


Table.4 Economic analysis of demonstrated plots and farmers practices

\begin{tabular}{|c|c|c|c|c|c|c|c|c|}
\hline & \multicolumn{2}{|c|}{$\begin{array}{c}\text { Average cost of } \\
\text { cultivation (Rs./ha) }\end{array}$} & \multicolumn{2}{c|}{$\begin{array}{c}\text { Average gross return } \\
\text { (Rs./ha) }\end{array}$} & \multicolumn{2}{c|}{$\begin{array}{c}\text { Average net return } \\
\text { (Rs./ha) }\end{array}$} & \multicolumn{2}{c|}{ B:C ratio } \\
\hline Season & Demonstration & Check & Demonstration & Check & Demonstration & Check & Demonstration & Check \\
\hline $2015-16$ & 24680 & 26283 & 60,260 & 50,887 & 35,580 & 24604 & 2.44 & 1.94 \\
\hline $2016-17$ & 25720 & 26520 & 51,522 & 43,152 & 25,802 & 16,632 & 2.00 & 1.63 \\
\hline $2017-18$ & 26345 & 27365 & 50,732 & 44,408 & 24,387 & 17,043 & 1.92 & 1.62 \\
\hline $2018-19$ & 26650 & 27450 & 66,048 & 53,760 & 39,398 & 26,310 & 2.47 & 1.96 \\
\hline Mean & 25848.75 & 26904.5 & 58,390 & 53,760 & $31,291.75$ & 19,995 & 2.21 & 1.79 \\
\hline
\end{tabular}

\section{Cost-benefit analysis}

Economic returns from demonstrations were compared with check plots and data are given in Table 4. The expenditure incurred on different crop inputs viz., seed, herbicide, seed treatment, land preparation and pesticides was considered for calculating the cost of cultivation whereas gross returns were calculated on the basis of actual market sale price of the produce availed by the farmers. It can be observed that cost of cultivation was less in demonstrations of summer moong in comparison to check plots. It may be attributed to the use of non-recommended pesticides and their indiscriminate application for insect pest management on summer moong crop in check plots. The improved technologies of summer moong variety SML 832 gave higher mean net return of Rs. 39398/- per hectare with a benefit cost ratio 2.47 as compared to farmers practice (Rs. 26310/- per hectare benefit cost ratio 1.96) during 2018-19. Net returns in demonstrations were on higher side during all the years. The benefit-cost ratio (B:C ratio) was calculated during different years in summer moong. In summer moong B:C ratio was 2.44, 2.00, 1.92 and 2.47 for the year 2015-16, 2016-17, 201718 and 2018-19 respectively. The results are in agreement with the study of Singh et al. (2012), Kumar et al. (2015) and Singh et al. (2017 a).
The results of the study clearly indicate the positive effects of frontline demonstrations over the existing practices toward enhancing the yield of summer moong in the district. The productivity enhancement under front line demonstration over traditional method of summer moong cultivation created greater awareness and motivated the other farmers to adopted appropriate production technology of summer moong in adopted district. The selection of specific technology like improve variety, seed treatment, seed inoculation with bio-fertilizers, recommended dose of Phosphorus, Pre-emergence weed management and plant protection measure were undertaken in a proper way. Frontline demonstration was effective in changing attitude of farmers towards pulse cultivation. Cultivation of demonstrated plots of summer moong with improved technologies has increased the skill and knowledge of the farmers. Demonstration also helped in replacement of local unrecommended varieties with improved recommended varieties. This also improved the relationship between farmers and scientist and built confidence between them.

\section{References}

Choudhary, B. N. 1999. Krishi Vigyan Kendra - A Guide for KVK Managers. Publication, Division of Agricultural Extension, ICAR, 73 - 78.

Kumar, S. and Kispotta, W. 2017. Impact of frontline demonstration on summer 
moong through improved technology in bhadohi district of Uttar Pradesh, India. Plant Arc. 17(1): 423-426.

Samui, S. K., Mitra, S., Roy, D.K., Mandal, A.K. and Saha, D. 2000. Evolution of frontline demonstration on groundnut. $J$. Indian Soc. Coastal Agric. Res., 18 (2): 180-183.

Singh, D., Singh, K.B., Gill, N.S. and Grewal, I.S. 2017 a. Impact analysis of frontline demonstrations on pulses in Punjab. Int. J. Farm Sci. 7(1): 190-194.

Singh, J., Dhillon, B.S., Astha and Singh, P. 2012. Front line demonstration - An effective tool for increasing the productivity of summer moong in Amritsar district of Punjab. Asian J. Soil Sci. 7(2): 315-318.

Singh, S., Rajni, and Walia, S.S. 2017 b. Evaluation and Analysis of Gaps in Adoption of Improved Pulse Production Technology in Punjab. Indian Res. J. Ext. Edu. 17(2): 69-72.

Sunil Kulkarni, M. Shobharani and Raja. 2019. Integrated Management of Yellow Mosaic Disease (YMD) of Moongbean. Int. J. Curr. Microbiol. App. Sci. 8(8): 859-864.

\section{How to cite this article:}

Pawan Kumar and Arpandeep Kaur Boparai. 2020. Impact of summer moong through improved technology in Jalandhar district of Punjab, India. Int.J.Curr.Microbiol.App.Sci. 9(05): 3495-3501. doi: https://doi.org/10.20546/ijcmas.2020.905.415 